\title{
Can disability studies contribute to client-centred occupational therapy practice?
}

\author{
Cathy McCormack ${ }^{1}$ and Bethan Collins ${ }^{2}$
}

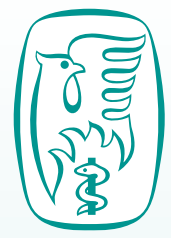

Key words:

Disability studies, disabled people, client-centred practice, occupational therapy, practice.

\footnotetext{
${ }^{1}$ Trinity College Dublin.

${ }^{2}$ Bournemouth University.
}

Corresponding author: Cathy McCormack, Practice Education Coordinator, Discipline of Occupational Therapy, Trinity College Dublin, Trinity Centre for Health Sciences, St James's Hospital, James's Street, Dublin 8. Email: cmccorm@tcd.ie

Reference: McCormack C, Collins B (2010) Can disability studies contribute to client-centred occupational therapy practice? British Journal of Occupational Therapy, 73(7), 339-342.

DOI: 10.4276/030802210X12785840213328

(C) The College of Occupational Therapists Ltd. Submitted: 12 October 2009.

Accepted: 15 April 2010.
Occupational therapists frequently cite a 'client-centred' approach as a fundamental aspect of their practice. However, there are many examples in the narratives of disabled people that suggest that the health and social care services they experience do not quite meet this aspiration. The authors propose that an understanding of disability from disabled people's perspectives is elemental to client-centred practice and that knowledge of the academic discipline of disability studies can contribute to authentic client-centred occupational therapy.

\section{Introduction}

Occupational therapy asserts that 'client-centred' practice is core to its philosophy (Canadian Association of Occupational Therapists 1997, 2002). We argue that, in order to practise client-centred occupational therapy with disabled people, occupational therapists need to have an appreciation of the concept of 'disability' from the viewpoints of disabled people.

One way of gaining an appreciation of disabled people's points of view is to embrace the academic discipline of disability studies, which is 'the study of disabled people's lifestyles and aspirations' (Finkelstein 1998, p33).

Throughout this article, we use the term 'disabled people' rather than 'people with disabilities'. This is out of deference for the contemporary debate in the field of disability studies, which questions the appropriateness of using 'people-first' language. Albrecht et al (2001, p3) declared that some disability studies scholars claim that the term 'people with disabilities' is an offensive term, promoted by powerful nondisabled people to emphasise that disability is part of the person rather than a social construct. This argument has also been articulated by some occupational therapy scholars, such as Kielhofner (2005) and Hammell (2006). The term 'disabled people' is preferred because it evokes the oppression that people with impairments experience due to a 'disabling' society. In other words, 'people with disabilities' suggests that the person is the one with the disability; a disabled person is someone who is disabled, for example by the environment.

This opinion piece defines disability studies, discusses occupational therapy and disability, outlines 'client-centred practice' and then proposes how disability studies and disability theory can contribute to client-centred practice with disabled people.

\section{Disability studies}

Disability studies is an interdisciplinary academic discipline drawing on sociology, linguistics, economics, anthropology, politics, history, psychology and media studies' (Swain et al 2003, p33) that 'reframes the study of disability by focusing on it as a social phenomenon and social construct' (Linton et al 1994, quoted in Pfeiffer and Yoshida 1995, p480).

With an ever-increasing number of programmes of study ranging from bachelor's and master's to PhD degrees in disability studies, this academic 
field is contributing substantially to the exploration of the environmental factors that disable people and to the examination of social, cultural and political methods of intervention that can confront barriers to disabled people's occupational engagement and social inclusion.

A core premise of disability studies is that it challenges the view of disability as an individual deficit or defect that can be remedied through medical intervention or rehabilitation by 'experts', such as occupational therapists: 'This shift of emphasis from a prevention/treatment/remediation paradigm to a social/cultural/political paradigm both emanates from and supports the Disability Rights movement' (Linton et al 1994, quoted in Pfeiffer and Yoshida 1995, p480) and underscores the 'discipline's commitment to advancing the social and political rights of disabled people' (Hammell 2006, p11).

\section{Occupational therapy and disability}

Within disability studies, there are explorations of a dichotomy between the perspectives that health professionals have of disability and the perspectives that disabled people have of disability (Abberley 1995, Beresford 2004, Gillman 2004, Shakespeare 2006).

Trickett et al (1994, p18, quoted in Linton 1998, p527) described the rehabilitation professions as 'person-fixing rather than context-changing'. In fact, some scholars argue that occupational therapy is oppressive owing to its tendency to adopt a medical model of disability to inform its practice (Jongbloed and Crichton 1990, Hunt 1996, Abberley 2004). When occupational therapists adopt a medical model of disability, there can be a tendency for them habitually to view disability in terms of biological and psychological processes and mechanisms and as an individual issue requiring intervention. This is in contrast to the social model of disability that is commonly used by disability studies scholars, which views disability as a social construct that can act as a barrier to disabled people's occupational engagement (Oliver 1990).

Disability theorists like Jongbloed and Crichton (1990, p32) have challenged occupational therapists to 'embrace a socio-political model of disability and be less willing to accept individual explanations for problems that are essentially economic, social or political'. However, Hammell (2006) contended that the occupational therapy profession has been slow to respond to the social model, citing Craddock (1996a, 1996b), and asserted as an illustrative argument that although there are some notable exceptions, most occupational therapy textbooks still conform to the medical model of disability.

This individualisation of disability by occupational therapists can result in an overemphasis on occupational therapy intervention that is aimed at remediating individual deficits, rather than intervention that takes a broader societal approach to enablement and social inclusion.
Kielhofner (2005) stated that disability studies scholars challenge occupational therapists to reconsider practice, education and research to question whether or not occupational therapy, at its essence, perpetuates oppression or helps to dismantle barriers to inclusion faced by disabled people.

\section{Client-centred practice}

Client-centred practice is considered to be a key component of good practice and has been articulated in many ways. One example is from Law et al (1995), who stated that client-centred practice is:

An approach to providing occupational therapy, which embraces a philosophy of respect for and partnership with people receiving services. It recognises the autonomy of individuals, the need for client choice in making decisions about occupational needs, the strengths clients bring to an occupational encounter and the benefits of client-therapist partnership and the need to ensure that services are accessible and fit the context in which a client lives (p253).

Sumsion and Law (2006) argued that different definitions of client-centred practice share many similar components and they defined five core elements of client-centred practice, which are described below.

1. Power: By virtue of their status as health professionals, occupational therapists possess power and there can often be a power differential between occupational therapists and disabled people. If the occupational therapist does not address the balance of power by shifting the balance towards the client, then his or her practice may actually be oppressive and disempowering of disabled people.

2. Listening and communication: Occupational therapists can address the balance of power through effective listening and communication skills. This should include listening to the client's values and beliefs concerning his or her experience of disability.

3. Partnership: This involves moving away from traditional authoritarian therapeutic styles of relating to the client and moving towards a style of relating to the client that respects the client's experiences and affords him or her similar status in the therapeutic relationship.

4. Choice: Occupational therapists should take cognisance of the client's values and wishes and afford the client an opportunity to choose his or her preferred course of action throughout the occupational therapy process.

5. Hope: Occupational therapists should acknowledge the importance of spirituality in each person's journey and respect the client's personal definition of hope and perspective on his or her own 'wellness'.

Fundamentally, the concept of 'client-centred practice' requires a partnership between the client and the therapist. Central to this partnership is the therapist's readiness to listen to the client's perspective on what 'disability' actually is and what his or her lived experience of disability is actually like. 
Fig. 1. Linking the five core elements of client-centred practice (Sumsion and Law 2006) with specific disability studies theoretical concepts.

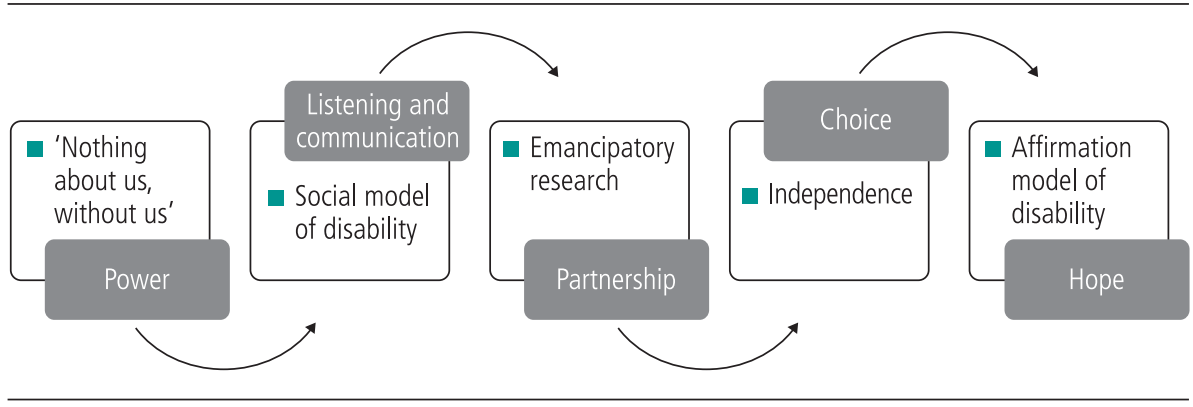

\section{Disability studies can contribute to client-centred practice}

By using the five core elements of client-centred practice delineated by Sumsion and Law (2006) as an analytical structure, Fig. 1 links specific disability studies theoretical concepts to each of these client-centred elements. It thus illustrates the contribution that disability studies can make to the perceptible realisation of client-centred practice.

\section{Power}

French (1994, p103) stated that the relationship between professionals and disabled people is an unequal relationship with the professionals holding most of the power. Traditionally professional workers have defined, planned and delivered services, while disabled people have been passive recipients with little if any opportunity to exercise control'. Barnes and Mercer (2003) maintained that disabled people perceive their relationships with professionals to be hierarchical, with professionals intent on reinforcing their own power and the powerlessness of disabled people. Hammell (2006) stated that 'regrettably, these perspectives have been unaffected by two decades of self-professed "client-centred" practice'. Therefore, as Thompson (1998, p43) argued, 'an understanding of the workings of power is an essential part of challenging inequality, discrimination and oppression'. Central to this concept of redistributing the balance of power is the disability studies concept of 'Nothing about us, without us' (Charlton 1998), where decisions that affect disabled people are made by disabled people rather than by professionals.

\section{Listening and communication}

Many disabled people perceive disability through the social model of disability. This model perceives disability as being caused by society and views a disabled person as someone who is disadvantaged by society. Therapists aware of this model can challenge their propensity for individualistic disability ideology and practice in a way that can improve the circumstances of disabled people through changes in social policies and procedures and by addressing environmental barriers, be they physical, social, cultural or institutional. In doing so, they respect the disabled person's values and beliefs around disability being a social construct and they can then genuinely endeavour to work together with the disabled person to address the environmental barriers that can result in disability.

\section{Partnership}

Shakespeare (2006, p186) contended that 'historically research and policy was dominated by proxies for disabled people (parents, carers, professionals), now it is the views of disabled people themselves which matter most. Rather than seeing disabled people as objects of care and concern, disabled people are seen as subjects, entitled to choices and inclusion. The ideals of emancipatory research suggest that the research agenda should be generated by disabled people and that researchers - whether disabled or non-disabled - should be accountable to organisations of disabled people.'

\section{Choice}

In order to provide choice, self-reflection on the therapist's own values and beliefs may be required. One example of this relates to the concept of independence.

Reindal (1999, p353) stated that 'professionals tend to define independence in terms of self-care activities so independence is measured against skills in relation to the performance of these activities'. This ideology of 'independence' is often unchallenged by therapists, who assume that their belief in the importance of independence of this nature is universally shared. Whiteford and Wilcock (2000, p332) even went as far to say that independence in everyday tasks is a 'concept with which occupational therapists have become fixated'. Disabled people, however, define independence as an ability to be in control of and make decisions about their lives and value the 'importance of being able to make autonomous decisions: to be in control of their lives' (Lund and Nygård 2004). If the occupational therapist appreciates these different perspectives, practice is more likely to respond to the client's personal choices and autonomy rather than making assumptions around the client's needs and responding in a potentially oppressive way.

\section{Hope}

An interesting development in disability studies in recent times is the move away from personal tragedy views of disability (like the medical model of disability) (Morris 1991) and a move towards recognising positive views of disability. This positive view of disability is best expressed in the affirmation model of disability (Swain and French 2000). This model asserts a positive identity in being disabled and rejects presumptions of dependency and abnormality. This positive model of disability is 'borne of disabled people's experiences as valid individuals, as determining their own lifestyles, culture and identity' (p578). 
Through an appreciation of the existence of the affirmation model of disability, the occupational therapist can respect the client's personal definition of hope and his or her perspective on his or her own wellness.

\section{Conclusion}

In contributing to the understanding of disability from the viewpoints of disabled people and disability theorists, the academic discipline of disability studies can stimulate occupational therapists to reflect on their own viewpoints and assumptions around the nature of disability and to enact change in their professional engagement with disabled people. This will ensure that their practice is sensitive to disabled people's viewpoints and to their actual lived experiences of disability. Through this legitimisation of disabled people's knowledge and experience, occupational therapists can transform the ways in which their service is delivered and truly 'translate client-centred rhetoric into client-centred practice' (Hammell 2006, p157).

\section{References}

Abberley P (1995) Disabling ideology in health and welfare - the case of occupational therapy. Disability and Society, 10(2), 221-32.

Abberley P (2004) A critique of professional support and intervention. In: J Swain, S French, C Barnes, C Thomas, eds. Disabling barriers - enabling environments. 2nd ed. London: Sage, ch. 36.

Albrecht GL, Seelman KD, Bury M (2001) Handbook of disability studies. Thousand Oaks, CA: Sage.

Barnes C, Mercer G (2003) Disability. Cambridge: Polity Press.

Beresford P (2004) Treatment at the hands of professionals. In: J Swain, S French, C Barnes, C Thomas, eds. Disabling barriers - enabling environments. 2nd ed. London: Sage, ch. 37.

Canadian Association of Occupational Therapists $(1997,2002)$ Enabling occupation: an occupational therapy perspective. Ottawa, ON: CAOT Publications ACE.

Charlton JI (1998) Nothing about us without us: disability oppression and empowerment. Berkeley, CA: University of California Press.

Craddock J (1996a) Responses of the occupational therapy profession to the perspective of the disability movement, part 1. British Journal of Occupational Therapy, 59(1), 17-22.

Craddock J (1996b) Responses of the occupational therapy profession to the perspective of the disability movement, part 2. British Journal of Occupational Therapy, 59(2), 73-78.

Finkelstein V (1998) Emancipating disability studies. In: T Shakespeare, ed. The disability studies reader: social science perspectives. London: Cassell.

French S (1994) Disabled people and professional practice. In: S French, ed. On equal terms: working with disabled people. Oxford: ButterworthHeinemann, 103-18.
Gillman M (2004) Diagnosis and assessment in the lives of disabled people: creating potentials/limiting possibilities? In: I Swain, S French, C Barnes, C Thomas, eds. Disabling barriers - enabling environments. 2nd ed. London: Sage, ch. 38.

Hammell K (2006) Perspectives on disability and rehabilitation: contesting assumptions; challenging practice. Edinburgh: Churchill Livingstone.

Hunt J (1996) Joining in the dialogue set by disabled people. (Letter.) British Journal of Occupational Therapy, 59(5), 243.

Jongbloed L, Crichton A (1990) A new definition of disability: implications for rehabilitation practice and social policy. Canadian Journal of Occupational Therapy, 57(1), 32-38.

Kielhofner G (2005) Rethinking disability and what to do about it: disability studies and its implications for occupational therapy. American Journal of Occupational Therapy, 59(5), 487-96.

Law M, Baptiste S, Mills J (1995) Client-centred practice: what does it mean and does it make a difference? Canadian Journal of Occupational Therapy, 62(5), 250-57.

Linton S, Mello S, O'Neill J (1994) Locating disability in diversity. In: E Makas, L Schlesinger, eds. Insights and outlooks: current trends in disability studies. Portland, ME: Society for Disability Studies/Edmund S Muskie Institute of Public Affairs. Cited in: Pfeiffer D, Yoshida K (1995) Teaching disability studies in Canada and the USA. Disability and Society, 10(4), 475-500.

Lund ML, Nygård L (2004) Occupational life in the home environment: the experiences of people with disabilities. Canadian Journal of Occupational Therapy, 71(4), 243-51.

Morris J (1991) Pride against prejudice: transforming attitudes to disability. London: The Women's Press.

Oliver M (1990) The politics of disablement. London: Macmillan.

Reindal SM (1999) Independence, dependence, interdependence: some reflections on the subject and personal autonomy. Disability and Society, 14(3), 353-67.

Shakespeare T (2006) Disability rights and wrongs. London: Routledge.

Sumsion T, Law M (2006) A review of the evidence on the conceptual elements informing client centred practice. Canadian Journal of Occupational Therapy, 73(3), 153-62.

Swain J, French S (2000) Towards an affirmation model of disability. Disability and Society, 15(4), 569-82.

Swain J, French S, Cameron C (2003) Controversial issues in a disabling society. Maidenhead: Open University Press.

Thompson N (1998) Promoting equality: challenging discrimination and oppression in the human services. Houndmills: Macmillan.

Trickett EJ, Watts RJ, Birdman D, eds (1994) Toward an overarching framework for diversity. Human diversity perspectives on people in context. San Francisco: Jossey-Bass. Cited in: Linton S (1998) Disability studies/not disability studies. Disability and Society, 13(4), 525-40.

Whiteford GE, Wilcock AA (2000) Cultural relativism: occupation and independence reconsidered. Canadian Journal of Occupational Therapy, 67(5), 324-36. 